\title{
Analisis Pengaruh Kinerja Perbankan terhadap Dana Pihak Ketiga Pada Bank Umum Konvensional
}

\author{
Kurniawan Hulu \\ Universitas Prima Indonesia \\ kurniawanhulu01@gmail.com
}

\author{
Ferdy Halim \\ Universitas Prima Indonesia \\ ferdyhalim55@gmail.com
}

\section{Novita \\ Universitas Prima Indonesia \\ novitawang37@gmail.com}

\section{Thomas Firdaus}

Universitas Prima Indonesia

firdausthom@yahoo.com

\begin{abstract}
Abstrak
Tujuan penelitian ini dilakukan ialah untuk menganalisis pengaruh kinerja perbankan terhadap dana pihak ketiga pada bank umum konvensional, adapun variabel yang diteliti ialah Biaya Operasional Terhadap Pendapatan Operasional (BOPO), Capital adequancy Ratio (CAR), Return On Asset (ROA) dan Loan to Deposit Ratio (LDR) terhadap Dana Pihak Ketiga. Data sekunder pada laporan keuangan OJK merupakan data yang digunakan dalam penelitian ini dengan periode 2016-2019. Teknik pengumpulan data yang di pakai menggunakan teknik dokumentasi data dengan jumlah sampel sebanyak empat puluh (40) dan seratus delapan (108) populasi. Hasil dari analisis data menunjukkan, secara simultan BOPO, CAR ROA dan LDR berpengaruh signifikan terhadap Dana Pihak Ketiga sedangkan secara parsial BOPO, CAR, ROA dan LDR berpengaruh signifikan terhadap Dana Pihak Ketiga. Dari uji koefisien regresi didapatkan sebanyak $69,5 \%$ bahwa dana pihak ketiga dapat diuraikan oleh variabel-variabel independen.

Kata Kunci Biaya Operasional Terhadap Pendapatan Operasional,Capital adequancy Ratio, Return On Asset, Loan to Deposit Ratio, Dana Pihak Ketiga
\end{abstract}

\section{PENDAHULUAN}

Bank merupakan salah satu institusi yang berperan didalam perekonomian negara. Selain fungsinya sebagai tempat untuk menyimpan uang maupun dana, Bank juga memiliki kapasitas sebagai organisasi yang dapat membantu meningkatkan bantuan pemerintah daerah setempat dengan cara sebagai badan yang menyalurkan kredit kepada masyarakat yang ingin membuka usaha dan sebagainya. Namun apakah pengertian bank yang sebenarnya? Pengertian bank selama ini dikenal dengan tempat penyimpanan uang, namun menurut UU No.10 Tahun 1998 bank adalah substansi bisnis yang menghimpun aset dari masyarakat umum sebagai dana cadangan dan mengalokasikannya kepada masyarakat umum sebagai kredit dan bentuk-bentuk lainnya dalam rangka meningkatkan taraf hidup masyarakat. Bank adalah organisasi keuangan yang melakukan berbagai macam administrasi, seperti memberikan kredit, mengeluarkan uang tunai, memeriksa uang, berkeliling sebagai tempat penyimpanan barang-barang penting, organisasi organisasi pembiayaan, dll. Masyarakat dengan aset berlimpah dapat menyimpan aset mereka sebagai giro, penyimpanan waktu berjangka, dana cadangan, dan struktur yang berbeda berdasarkan kasus per kasus, yang disebut sebagai aset orang luar. Kemudian, individu yang membutuhkan atau 
membutuhkan aset dapat mengajukan uang muka atau kredit ke bank. Aset yang dikumpulkan dari catatan publik untuk sekitar $80 \%$ - 90\% dari aset lengkap mengawasi dan untuk latihan kredit mencapai 70\% - 80\% dari latihan bisnis bank. Sebagaimana ditunjukkan oleh Dahlan Siamat (2005) salah satu alasan sentralisasi pelaksanaan bank dalam peminjaman adalah gagasan bank sebagai mediator pembentukan antara unit surplus dan unit shortfall sehingga secara etis mereka harus menyalurkan aset tersebut kembali ke daerah setempat sebagai penambahan kredit. Membaiknya perbankan di negara agraris seperti Indonesia, sebagian besar sumber pembiayaan kegiatan usaha bersumber dari peminjaman yang diandalkan untuk menggairahkan pembangunan moneter. Kinerja perbankan dapat disurvei dari beberapa penanda. Salah satu penanda prinsip yang digunakan sebagai alasan evaluasi adalah laporan anggaran bank yang bersangkutan. Berdasarkan laporan anggaran, berbagai proporsi moneter yang biasa digunakan sebagai alasan untuk melakukan survei kecukupan suatu bank dapat ditentukan. Konsekuensi dari pemeriksaan laporan anggaran akan membantu menguraikan koneksi dan pola kunci yang berbeda yang dapat memberikan premis untuk memikirkan kemungkinan pencapaian organisasi di kemudian hari (Sunyoto dan Sam'ani, 2014). BOPO (beban kerja terhadap upah kerja), CAR (Proporsi Kecukupan Modal), Pengembalian Sumber Daya (ROA) dan kemampuan bank memenuhi kewajiban keuangan (LDR). Keempat sudut tersebut, yaitu capital, asset, earning dan liquidity dievaluasi secara spesifik dengan menggunakan proporsi moneter, hal ini menunjukkan bahwa proporsi moneter sangat berharga dalam mensurvei keadaan moneter suatu organisasi.

\section{LANDASAN TEORI}

1. $\quad$ BOPO (Biaya Operasional Terhadap Pendapatan Operasional)

Proporsi biaya kerja terhadap upah kerja (BOPO) sesuai dengan referensi kata moneter adalah kumpulan proporsi yang mengukur produktivitas dan kecukupan aktivitas organisasi dengan saling kontras. Angka-angka pembayaran dan konsumsi yang berbeda dari proklamasi pembayaran dan terhadap angka-angka pada catatan moneter. Proporsi biaya kerja merupakan proporsi antara biaya kerja dan upah kerja. Sesuai Rivai, dkk. (2013: 480) Proporsi BOPO merupakan pemeriksaan antara biaya kerja dan upah kerja dalam memperkirakan tingkat kemahiran dan kemampuan bank dalam melakukan aktivitasnya. Semakin rendah BOPO berarti semakin produktif bank dalam mengendalikan biaya operasionalnya, dengan efektifitas biaya maka semakin menonjol pula keuntungan yang akan diperoleh bank tersebut.

$$
\text { BOPO }=\frac{\text { Biaya Operasi }}{\text { Pendapatan Operasi }} \times 100 \%
$$

\section{CAR (Capital Adequacy Ratio)}

Capital Adequacy Ratio (CAR) adalah proporsi kecukupan modal yang berfungsi untuk menanggung risiko keuangan yang mungkin dihadapi bank. Semakin tinggi CAR, semakin baik kapasitas bank untuk menanggung bahaya kredit / perolehan sumber daya yang tidak aman. Jika ratio CAR tinggi, bank dapat mendukung kegiatan operasional dan membuat komitmen yang cukup besar untuk mendapatkan keuntungan. Capital Adequancy Ratio sebagaimana diindikasikan oleh Kasmir (2012: 325) adalah "kemampuan untuk menghitung modal dan simpanan untuk keuntungan dalam menyandang kredit, terutama bahaya yang terjadi karena bunga tidak dikumpulkan. CAR merupakan penanda dari suatu kapasitas bank untuk menutupi penurunan sumber daya karena kemalangan bank yang disebabkan oleh sumber daya berisiko

$$
\text { CAR }=\frac{\text { Modal Bank }}{\text { Total ATMR }} \times 100 \%
$$




\section{ROA (Return on Asset)}

Return On Asset adalah ratio antara total kompensasi yang berbanding terbalik dengan semua sumber daya untuk menghasilkan keuntungan. Ratio ini menunjukkan berapa banyak keuntungan bersih yang diperoleh organisasi diperkirakan oleh harga sumber dayanya. Pemeriksaan Return On Asset atau sering diartikan dalam bahasa indonesia sebagai perkiraan produktivitas finansial kemajuan organisasi yang menciptakan keuntungan sebelumnya. Kajian ini kemudian diproyeksikan ke masa depan untuk melihat kapasitas organisasi dalam menciptakan manfaat di kemudian hari. Seperti yang diindikasikan oleh Rivai, dkk (2013: 480 adalah kemampuan organisasi dalam memanfaatkan sumber dayanya untuk menghasilkan keuntungan

$$
\text { ROA }=\frac{\text { Laba Bersih }}{\text { Total Aktiva }} \times 100 \%
$$

\section{4. $\quad$ LDR (Loan to Deposit Ratio)}

Loan to Deposit Ratio adalah rasio kredit yang digunakan untuk survei likuiditas bank dengan membandingkan keseluruhan kredit bank dengan keseluruhan simpanannya untuk periode yang sama. Dalam hal perhitungan LDR menunjukkan proporsi yang tinggi, maka bank meminjamkan setiap aset yang dimilikinya, sehingga bank tersebut cukup likuid. Di sisi lain, dengan asumsi yield LDR tinggi, bank seharusnya likuid dengan kelebihan batas aset yang layak untuk dipinjamkan. Seperti yang diindikasikan oleh Kasmir (2014: 225) "LDR (Loan to Deposit Ratio) adalah proporsi yang digunakan untuk mengukur pengaturan ukuran kredit yang ditawarkan dibandingkan dengan ukuran aset publik dan modal yang digunakan.”. Proporsi ini mewakili kemampuan bank untuk mengganti penarikan yang dilakukan oleh investor dengan bergantung pada pinjaman yang diberikan sebagai sumber likuiditas.

$$
\text { LDR }=\frac{\text { Kredit }}{\text { Dana Pihak Ketiga }} \times 100 \%
$$

\section{Dana Pihak Ketiga}

Dana pihak ketiga sebagaimana digambarkan dalam Undang-Undang Keuangan Republik Indonesia Nomor 10 Tahun 1998 tentang Perbankan adalah cadangan yang diamanahkan oleh masyarakat pada umumnya kepada bank yang bergantung pada persetujuan untuk menyimpan aset sebagai deposit, giro, sertifikat, dana investasi, serta struktur identik lainnya. Menurut Kasmir (2012: 64), dana pihak ketiga adalah cadangan yang bersumber dari wilayah nasabah setempat yang lebih luas yang merupakan sumber utama aset untuk kegiatan operasional bank dan merupakan bagian dari pencapaian bank jika hal itu terjadi dapat mendukung aktivitas dari sumber aset ini. Dana pihak ketiga dibutuhkan oleh bank dalam menjalankan aktivitasnya.

\section{METODOLOGI PENELITIAN}

Peneliti melakukan pengkajian pada bank umum konvensional yang terdaftar di OJK, lewat situs www.ojk.go.id. Penelitian telah dilakukan sejak bulan februari 2021 - mei 2021. Peneliti menggunakan ancangan kuantitatif dalam pengkajian ini, tujuannya adalah menemukan hubungan sebab akibat antara independent variable (X) terhadap dependent variable (Y). Populasi penelitian merupakan data keuangan bank umum konvensional di OJL periode 2016 2019. Kaidah penelitian ialah purpose-sampling yaitu tipe pemilihan sample berdasarkan pertimbangan tujuan penelitian. Dari hasil pemilihan sample dengan metode purpose sampling terdapat empat puluh bank yang sesuai kriteria dari keseluruhan populasi sebanyak seratus delapan bank. Jadi total jumlah sample sebanyak seratus enam puluh data perusahaan setelah dikalikan 4 (empat) tahun. Pengumpulan data yang digunakan ialah teknik informasi sekunder melalui dokumentasi laporan keuangan perusahaan yang terdaftar di OJK periode 2016 - 2019. Teknik pengambilan data dalam pengujian ini menggunakan uji asumsi klasik yang terdapat 
empat (4) bagian pengujian dalam model regresi antara lain, Untuk menyelidiki variable pengganggu telah berdistribusi normal atau sebaliknya, ialah menggunakan uji normalitas, Untuk menyelediki terdapat atau tidak distingsi varians dengan residual 1 peninjauan pada peninjauan lainya, ialah menggunakan uji heteroskedastisitas, Untuk menyelidiki terjadi atau tidak interelasi antar independent variable atau tidak ialah menggunakan uji multikoloniearitas, Untuk menyelidiki terdapat atau tidak distingsi antar kesalahan pengganggu dari fase $t$ ke fase $t-1$ (sebelumnya), adalah menggunakan uji autokorelasi. Pada pengujian ini, penelitian dilakukan dengan analisis regresi linear berganda memakai model penelitian antara lain,

Y = Dana Pihak Ketiga,

$$
\mathrm{Y}=\mathrm{a}+\mathrm{b}_{1} \mathrm{X}_{1}+\mathrm{b}_{2} \mathrm{X}_{2}+\mathrm{b}_{3} \mathrm{X}_{3}+\mathrm{e} \text { dimana }
$$

$\mathrm{a}=$ konstantan,

$\mathrm{X} 1$ = Beban Operasional terhadap Biaya operasional,

$\mathrm{X} 2$ = Capital Adequancy Ratio,

B1b2b3 = Koefisien Regresi ,

$\mathrm{X} 3=$ Return On Asset,

$\mathrm{X} 4=$ Loan to Deposit Ratio dan

$\mathrm{e}=$ kekeliruan (error)

sedangkan untuk pengujian kemampuan independent variable menjelaskan dependent variable dapat digunakan uji koefisien determinasi (R2). Untuk menjelaskan seberapa besar independent dijelaskan oleh seluruh dependent adalah menggunakan uji $\mathrm{F}$ dan untuk menyelidiki signifikan pengaruh dari beberapa independent (X1X2X3X4) terhadap dependent $(\mathrm{Y})$ menggunakan uji statistik (uji t).

\section{HASIL PENELITIAN}

IV.1. DESCRIPTIVE STATISTIC

Tabel 1. Statistika Deskripif

\begin{tabular}{|l|c|r|r|r|r|}
\hline \multicolumn{7}{|c|}{ Descriptive Statistics } \\
\hline & $\mathrm{N}$ & Minimum & Maximum & \multicolumn{1}{c|}{ Mean } & Std. Deviation \\
\hline LN_BOPO & 160 & 3.93 & 4.60 & 4.3970 & .14687 \\
\hline LN_CAR & 160 & 2.35 & 4.20 & 3.1454 & .31052 \\
\hline LN_ROA & 160 & -2.41 & 1.52 & .3304 & .81827 \\
\hline LN_LDR & 160 & 3.92 & 5.28 & 4.5343 & .23577 \\
\hline LN_DPK & 160 & 12.88 & 20.69 & 16.8890 & 1.82058 \\
\hline Valid N (listwise) & 160 & & & & \\
\hline
\end{tabular}

Variabel LN_BOPO memiliki sampel 160 dengan nilai dasar 3,93 dan nilai terbesar 4,60 sedangkan nilai normalnya adalah 4,3970 dengan standar deviasi 0,14687 . Variabel LN_CAR memiliki sampel 160 dengan nilai dasar 2,35 dan nilai paling besar 4,20 sedangkan nilai normalnya adalah 3,1454 dengan deviasi standar 0,31054. Variabel LN_ROA memiliki sampel 160 dengan nilai dasar - 2,41 dan nilai paling besar 1,52 sedangkan nilai normalnya adalah 0,3304 dengan deviasi standar 0,81827. Variabel LN_LDR memiliki sampel 160 dengan nilai dasar 3,92 dan nilai paling besar 5,28 sedangkan nilai normalnya adalah 4,5343 dengan standar deviasi 0,23577. Variabel LN_DPK memiliki sampel 160 dengan nilai dasar 12,88 dan nilai paling besar 20,69, sedangkan nilai normalnya adalah 16,8890 dengan standar deviasi 1,82058.

\section{IV.2. ASUMSI KLASIK}

a. Uji Normalitas

1. Analisis Grafik 


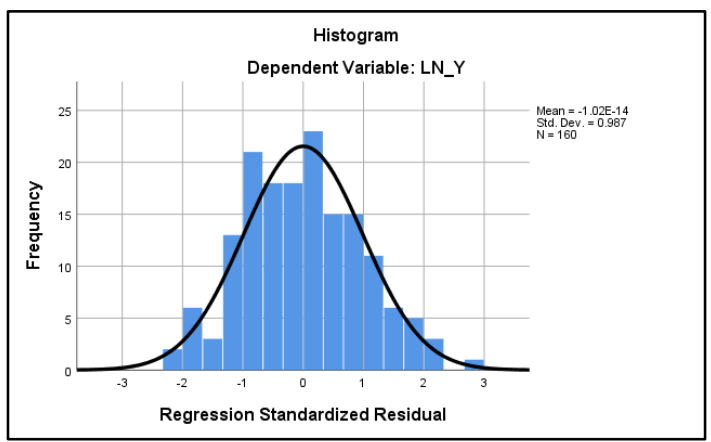

\section{Gambar 1. Grafik Histogram setelah Transformasi data}

Dari grafik histogram di atas, kurva menunjukan pola data yang berdistribusi normal pada setiap variabel di karenakan berbentuk lonceng dan kemiringan yang hamper setara.

\section{P-Plot}

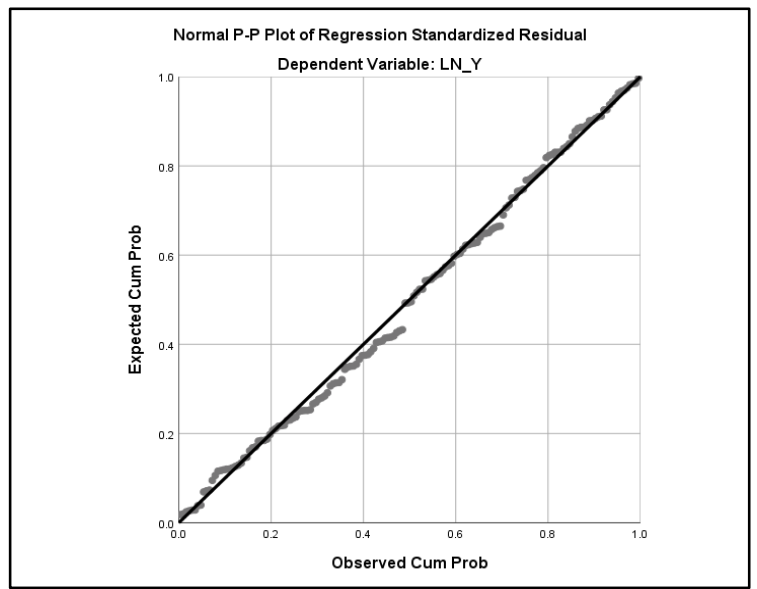

\section{Gambar 2. Normality P-Plot setelah Transformasi Data}

Berdasarkan hasil dari P-Plot terlihat titik tidak tersebar dan mengikuti arah garis diagonalnya, maka dapat dikatakan data berdistribusi dengan baik.

3. Uji Kolmogorov-Smirnov

\begin{tabular}{|c|c|c|}
\hline \multicolumn{3}{|c|}{ One-Sample Kolmogorov-Smirnov Test } \\
\hline & & $\begin{array}{l}\text { Unstandardiz } \\
\text { ed Residual }\end{array}$ \\
\hline $\mathrm{N}$ & & 160 \\
\hline \multirow[t]{2}{*}{ Normal Parameters ${ }^{a, b}$} & Mean & .0000000 \\
\hline & Std. Deviation & 1.30823830 \\
\hline \multirow[t]{3}{*}{ Most Extreme Differences } & Absolute & .056 \\
\hline & Positive & .056 \\
\hline & Negative & -.031 \\
\hline Test Statistic & & .056 \\
\hline Asymp. Sig. (2-tailed) & & $.200^{\mathrm{c}, \mathrm{d}}$ \\
\hline \multicolumn{3}{|c|}{ a. Test distribution is Normal. } \\
\hline \multicolumn{3}{|c|}{ b. Calculated from data. } \\
\hline \multicolumn{3}{|c|}{ c. Lilliefors Significance Correction. } \\
\hline \multicolumn{3}{|c|}{ d. This is a lower bound of the true significance. } \\
\hline
\end{tabular}

Tabel 2. Uji Kolmogorov-Smirnov

Penentuan keputusan pada hasil pengujian kolmogorov-smirnov berdasarkan:

1. Bila signifikansinya $>0,05$ data tersebut berdistribusi normal,

2. Bila signifikansinya $<0,05$ data tersebut berdistribusi tidak normal. 
Melalui tabel diatas hasil uji nilai Kolmogorov Sminov sebesar 0,056 dan Asymp. Sig. (2-tailed) 0,200 dan nilai tersebut lebih besar dari 0,05 sehingga data terdistribusi secara normal. b. Uji Muitikolinieritas

\begin{tabular}{|c|c|c|c|}
\hline \multicolumn{4}{|c|}{ Coefficients $^{\mathrm{a}}$} \\
\hline \multirow{2}{*}{\multicolumn{2}{|c|}{ Model }} & \multicolumn{2}{|c|}{ Collinearity Statistics } \\
\hline & & Tolerance & VIF \\
\hline 1 & LN_BOPO & .396 & 2.524 \\
\hline & LN_CAR & .920 & 1.087 \\
\hline & LN_ROA & .445 & 2.246 \\
\hline & LN_LDR & .825 & 1.212 \\
\hline
\end{tabular}

Tabel 3. Uji Multikolinieritas

Berdasarkan pada tabel di atas VIF $<10$ dan tolerance $>0,1$ yang menandakan tidak adanya multikolinearitas dan tidak mengalami masalah. Maka kesimpulannya yakni tidak adanya multikolinearitas.

c. Uji Heteroskedastisitas

1. Scatterplot

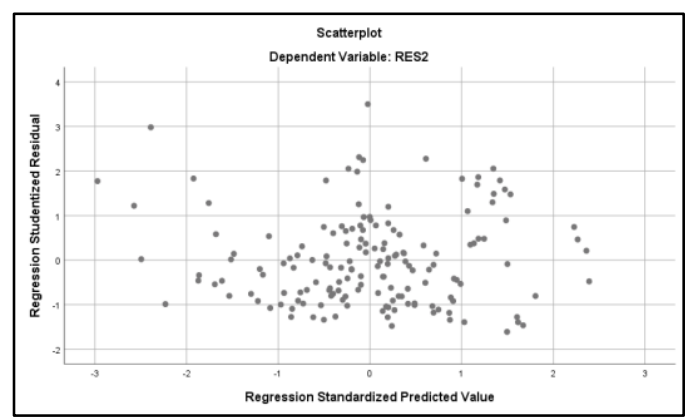

Gambar 3. Uji Scatterplot setelah transformasi data

Pada gambar Scatterplot LN_DPK di atas menunjukkan model regresi tidak memiliki gejala HETEROSKEDASTISITAS, ditandai dengan titik-titik yang menyebar dan tidak menumpuk.

2. Glejser

Tabel 4. Uji Glejser setelah Transformasi Data

\begin{tabular}{|c|c|c|c|c|c|}
\hline \multicolumn{6}{|c|}{ Coefficients $^{\mathrm{a}}$} \\
\hline \multirow[b]{2}{*}{ Model } & \multicolumn{2}{|c|}{ Unstandardized Coefficients } & \multirow{2}{*}{$\frac{\text { Standardized Coefficients }}{\text { Beta }}$} & \multirow[b]{2}{*}{$\mathrm{t}$} & \multirow[b]{2}{*}{ Sig. } \\
\hline & B & Std. Error & & & \\
\hline \begin{tabular}{|l|l|}
1 & (Constant)
\end{tabular} & 5.568 & 3.636 & & 1.531 & .128 \\
\hline LN_BOPO & -.479 & 643 & -.094 & -.745 & .457 \\
\hline LN_CAR & -.221 & .200 & -.091 & -1.105 & .271 \\
\hline LN_ROA & .095 & .109 & .103 & .869 & .386 \\
\hline LN_LDR & -.382 & .278 & -.120 & -1.375 & .171 \\
\hline
\end{tabular}

a. Dependent Variable: RES2

Dari hasil pengujian di tas nilai Sig diatas 0.05 untuk variabel LN_BOPO, LN_CAR, LN_ROA dan LN_LDR, yang berarti semua faktor tidak mengalami masalah HETEROSKEDASTISITAS. d. Uji Autokorelasi

Uji Run Test 
Tabel 5. Uji Run Test

\begin{tabular}{|l|r|}
\hline \multicolumn{2}{|c|}{ Runs Test } \\
\hline & Unstandardized Residual \\
\hline Test Value & a \\
\hline Cases $<$ Test Value & -26584436.57982 \\
\hline Cases $>=$ Test Value & 80 \\
\hline Total Cases & 160 \\
\hline Number of Runs & 71 \\
\hline$Z$ & -1.586 \\
\hline Asymp. Sig. (2-tailed) & .113 \\
\hline a. Median \\
\hline
\end{tabular}

Dari tabel di atas didapatkan nilai uji Run Test sebesar 0,113>0,05 maka tidak terdapat gejala AUTOKORELASI.

\section{IV.3. Uji Regresi Linear Berganda}

Tabel 6. Uji Regresi Linear Berganda

\begin{tabular}{|c|c|c|c|c|c|}
\hline \multicolumn{6}{|c|}{ Coefficients $^{\mathrm{a}}$} \\
\hline \multirow[b]{2}{*}{ Model } & \multicolumn{2}{|c|}{ Unstandardized Coefficients } & \multirow{2}{*}{$\frac{\text { Standardized Coefficients }}{\text { Beta }}$} & \multirow[b]{2}{*}{$\mathrm{t}$} & \multirow[b]{2}{*}{ Sig. } \\
\hline & B & Std. Error & & & \\
\hline $1 \quad$ (Constant) & 51.003 & 6.424 & & 7.939 & .000 \\
\hline LN_BOPO & -3.225 & 1.137 & -.260 & -2.837 & .005 \\
\hline LN_CAR & -4.090 & .353 & -.698 & -11.590 & .000 \\
\hline LN_ROA & .383 & .192 & .172 & 1.988 & .049 \\
\hline LN_LDR & -1.587 & .491 & -.205 & -3.234 & .001 \\
\hline
\end{tabular}

Dari hasil di atas, didapatkan persamaan regresi sebagai berikut:

$\mathrm{Y}=\mathrm{a}+\mathrm{b}_{1} \mathrm{X}_{1}+\mathrm{b}_{2} \mathrm{X}_{2}+\mathrm{b}_{3} \mathrm{X}_{3}+\mathrm{b}_{4} \mathrm{X}_{4}+\mathrm{e}$

$\mathrm{Y}=51,003-3,225 \mathrm{X}_{1}-4,090 \mathrm{X}_{2}+0,383 \mathrm{X}_{3}-1,587 \mathrm{X}_{4}+\mathrm{e}$

IV.4. Uji Hipotesis

1. Uji F (Simultan)

Tabel 7. Uji F setelah transformasi data

\begin{tabular}{|c|c|c|c|c|c|}
\hline \multicolumn{6}{|c|}{ ANOVA $^{a}$} \\
\hline Model & Sum of Squares & df & Mean Square & $\mathrm{F}$ & Sig. \\
\hline 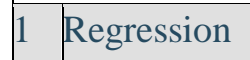 & 254.883 & 4 & 63.721 & 36.295 & $.000^{\mathrm{b}}$ \\
\hline Residual & 272.127 & 155 & 1.756 & & \\
\hline Total & 527.009 & 159 & & & \\
\hline
\end{tabular}

Dari hasil pengujian di atas diperoleh $F$ hitung sebesar 36,295 dengan F tabel 2,43. Nilai sig sebesar 0,000. Artinya nilai 36.295> 2.43 mengandung arti bahwa variabel independen secara simultan mempengaruhi variabel dependen (Dana Pihak Ketiga).

2. Uji T ( Parsial) 
Tabel 8. Uji T setelah Transformasi data

\begin{tabular}{|c|c|c|c|c|c|c|}
\hline \multicolumn{7}{|c|}{ Coefficients $^{\mathrm{a}}$} \\
\hline \multirow{2}{*}{\multicolumn{2}{|c|}{ Model }} & \multicolumn{2}{|c|}{ Unstandardized Coefficients } & \multirow{2}{*}{$\begin{array}{c}\begin{array}{c}\text { Standardized } \\
\text { Coefficients }\end{array} \\
\text { Beta } \\
\end{array}$} & \multirow[b]{2}{*}{$\mathrm{t}$} & \multirow[b]{2}{*}{ Sig. } \\
\hline & & B & Std. Error & & & \\
\hline 1 & (Constant) & 51.003 & 6.424 & & 7.939 & .000 \\
\hline & LN BOPO & -3.225 & 1.137 & -.260 & -2.837 & .005 \\
\hline & LN_CAR & -4.090 & .353 & -.698 & -11.590 & .000 \\
\hline & LN ROA & .383 & .192 & .172 & 1.988 & .049 \\
\hline & LN_LDR & -1.587 & .491 & -.205 & -3.234 & .001 \\
\hline
\end{tabular}

Berdasarkan tabel di atas maka hasil yang di dapat ialah :

Uji T BOPO untuk dana pihak ketiga adalah $t_{\text {hitung }}-2,837$ sedangkan nilai $t_{\text {tabel }} 1,975$. Jadi $-2,837$ $<1,975$ dengan nilai sig $0,005<0,05$ yang berarti $\mathrm{H}_{0}$ ditolak dan $\mathrm{H}_{\mathrm{a}}$ diakui, maka variabel BOPO secara parsial mempengaruhi variabel dana pihak ketiga. Uji T CAR untuk dana pihak ketiga adalah nilai $t_{\text {hitung }}$ sebesar -11,590 sedangkan nilai $t_{\text {tabel }}$ adalah 1,975. Jadi $-11,590<1,975$ dengan nilai sig $0,000<0,05$, yang berarti bahwa $\mathrm{H}_{0}$ ditolak dan $\mathrm{H}_{\mathrm{a}}$ diakui, maka variabel CAR secara parsial mempengaruhi variabel dana pihak ketiga. Uji T ROA untuk dana pihak ketiga adalah nilai $t_{\text {hitung }}$ sebesar $-1,988$ sedangkan nilai $t_{\text {tabel }}$ adalah 1,975. Jadi $-1,988<1.975$ dengan nilai sig $0,000<0,05$, yang berarti bahwa $\mathrm{H}_{0}$ ditolak dan $\mathrm{H}_{\mathrm{a}}$ diakui, maka variabel ROA secara parsial mempengaruhi variabel dana pihak ketiga. Uji T LDR untuk dana pihak ketiga adalah nilai thitung sebesar $-3,232$ sedangkan nilai $\mathrm{t}_{\text {tabel }}$ adalah 1,975. Jadi $-3,232<1.975$ dengan nilai sig $0,000<$ 0,05 , yang berarti bahwa $\mathrm{H}_{0}$ ditolak dan $\mathrm{H}_{\mathrm{a}}$ diakui, maka variabel LDR secara parsial mempengaruhi variabel dana pihak ketiga.

\section{IV.5. Koefisien Determinasi $\left(\mathbf{R}^{2}\right)$}

Tabel 9. Koefisien Determinasi $\left(\mathbf{R}^{2}\right)$

\begin{tabular}{|c|c|c|c|c|}
\hline \multicolumn{5}{|c|}{ Model Summary ${ }^{b}$} \\
\hline Model & $\mathrm{R}$ & R Square & Adjusted R Square & Std. Error of the Estimate \\
\hline 1 & $.695^{\mathrm{a}}$ & .484 & .470 & 1.32501 \\
\hline \multicolumn{5}{|c|}{ a. Predictors: (Constant), LN_LDR, LN_CAR, LN_ROA, LN_BOPO } \\
\hline \multicolumn{5}{|c|}{ b. Dependent Variable: LN_DPK } \\
\hline
\end{tabular}

Menurut tabel di atas diketahui nilai Adjusted $R$ Square adalah 0,470 dan nilai R sebesar 0,695. Pada penelitian ini dilihat berdasarkan nilai Adjusted $R$ Square yang berarti BOPO, CAR, ROA dan LDR dalam mengelaborasi variabel dana pihak ketiga adalah $69,5 \%$ sisanya $30,5 \%$ dipengaruhi oleh berbagai variabel yang tidak dianalisis.

\section{KESIMPULAN}

Berdasarkan hasil Uji F yang dilakukan pada penelitian ini menunjukkan bahwa ke-empat variabel yaitu BOPO, CAR, ROA dan LDR berpengaruh secara simultan terhadap Dana pihak ketiga. Berdasarkan hasil Uji T yang dilakukan pada penelitian ini menunjukkan bahwa ke-empat variabel yaitu BOPO, CAR , ROA dan LDR berpengaruh secara individu terhadap Dana pihak ketiga, yang berarti hipotesis ( $\mathrm{H} 1, \mathrm{H} 2, \mathrm{H} 3$ dan $\mathrm{H} 4)$ diterima. Berdasarkan hasil Koefisien Determinasi yang dilakukan keempat variabel (BOPO, CAR, ROA dan LDR) dalam menjelaskan 
variabel dana pihak ketiga (Y) adalah 69,5\% sisanya 30,5\% dipengaruhi oleh variabel lain yang tidak di teliti. Berdasarkan Hasil analisis linear berganda yang diteliti, variabel bebas BOPO, CAR dan LDR berpengaruh negatif terhadap variabel Dana Pihak Ketiga, sedangkan variabel ROA berpengaruh positif terhadap variabel Dana Pihak Ketiga.

\section{UCAPAN TERIMA KASIH}

Puji syukur kami (peneliti) panjatkan kepada Tuhan yang Maha Esa yang telah memberikan kami kesehatan, kekuatan, kesempatan dan anugerah-Nya sehingga kami dapat menyelesaikan skripsi ini dengan baik. Skripsi ini berjudul "Analisis Pengaruh Kinerja Perbankan Terhadap Dana Pihak Ketiga Pada Bank Umum Konvensional Yang Terdaftar Pada OJK Periode 2016-2019”, ditujukan sebagai syarat dalam memperoleh gelar Sarjana Ekonomi Program Studi Manajemen Keuangan pada Universitas Prima Indonesia. Selama melakukan penelitian dan penulisan jurnal ini, kami para peneliti mendapat banyak dukungan dan bantuan baik secara moril maupun material dari berbagai pihak. Oleh karena itu, pada kesempatan ini, kami ingin menyampaikan ucapan terima kasih, yakni kepada:

1. Ibu Dr. Chrismis Novalinda Ginting, S.Sit., M.Kes, selaku Rektor Universitas Prima Indonesia Medan.

2. Ibu Cut Fitri Rostina, S.E., M.M., selaku Dekan Fakultas Ekonomi Universitas Prima Indonesia Medan.

3. Bapak Hendry, S.E., M.M., selaku Wakil Dekan Fakultas Ekonomi Universitas Prima Indonesia Medan.

4. Ibu Fenny Krisna Marpaung, S.E., M.Si., selaku Ketua Program Studi S1 Manajemen Faktultas Ekonomi Universitas Prima Indonesia Medan.

5. Ibu Yeni Ariesa, S.E., M.Si. selaku sekretasis Jurusan Manajemen Fakultas Ekonomi Universitas Prima Indonesia Medan.

6. Bapak Thomas Firdaus Hutahaen, SE.,M.Si, ak, selaku pembimbing, atas bimbingan dan arahan dalam proses menyelesaikan penulisan jurnal ini.

7. Seluruh Staf Bagian Akademik Fakultas Ekonomi Universitas Prima Indonesia yang telah membantu dalam hal informasi dan administrasi selama kami para peneliti berada di Universitas Prima Indonesia.

8. Seluruh dosen-dosen yang selama ini telah membimbing dan membagi ilmunya selama kami duduk di bangku perkuliahan.

9. Kepada para Orang Tua tercinta yang selalu memberikan dukungan doa, perhatian dan dukungan moral maupun materil sehingga kami mampu menyelesaikan jurnal ini.

10. Kepada adik-adik peneliti dan teman-teman yang telah memberi semangat dalam pembuatan jurnal ini.

Kami menyadari masih banyak kekurangan dalam skripsi ini. Untuk itu, peneliti sangat mengharapkan adanya kritik dan saran yang bersifat membangun dari semua pihak yang berkesempatan untuk membaca jurnal ini.

\section{DAFTAR PUSTAKA}

Amelia, K. C. (2017). Analisis Pengaruh DPK, LDR, NPL DAN CAR Terhadap Jumlah Penyaluran Kredit Pada PT. BANK QNB INDONESIA, Tbk. Jurnal Ekonomi Bisnis Volume 22 No.1, April 2017, 22, 66-74.

Astutiningsih, K. W. (2019). Pengaruh CAR, DANA PIHAK KETIGA, UKURAN BANK, DAN LDR. E-Jurnal Manajemen Unud, Vol. 8, No. 3, 2019, 8, 1608 - 1636. 
Firdausi, I. (2016). Analisis Pengaruh Kinerja Perbankan terhadap Dana Pihak Ketiga Bank Persero. Keuangan dan Perbankan, Vol.20, No.3 September 2016, 20, 487-495.

Kamsir. (2012). Bank \& Badan Finasial Lainnya. Jakarta: PT. Raja Grafindo Persada.

Kamsir. (2012). Bank dan lembaga keuangan Lainnya. Jakarta: PT. Raja Grafindo Parsada.

Yudiana. (2013). Dasar-Dasar Manajemen Keuangan. Medan: Penerbit Ombak.

Situs Web: Otoritas Jasa Keuangan https://www.ojk.go.id

https://indomaritim.id/pengertian-bank-fungsi-dan-contohnya/

Putri R. 2014. Analisis Pengaruh Dana Pihak Ketiga (DPK), Capital Adequancy Ratio (CAR), Non Performing Loan (NPL) Dan Return On Assets (ROA) Terhadap Penyaluran Kredit Perbankan.Studi pada Bank Umum Go Public di Indonesia. Skripsi. Tidak Diterbitkan. Fakultas Ekonomi dan Bisnis. Universitas Diponegoro: Semarang. 